\title{
Türkçe Ders Kitabındaki Metinlerin Değerler Eğitimi Açısından İncelenmesi ve Öğretmen Görüşlerine Göre Değerlendirilmesi
}

\section{The Examination of Texts in Turkish Coursebooks in Terms of Values Education and Their Evaluation According to Teachers' Opinions}

\author{
Hatice COŞKUN, Sorumlu Yazar, Dr. Öğr. Üyesi. \\ Van Yüzüncü Yıl Üniversitesi, Van /Türkiye. \\ haticecoskun@yyu.edu.tr \\ https://orcid.org/0000000204538700
}

Gizem Ezgi DERSE, Yüksek Lisans Öğrencisi.

Van Yüzüncü Yıl Üniversitesi, Van /Türkiye.

gizemezgi@gmail.com

https://orcid.org/000000019241 4849

\author{
ISSN: 1303-880X \\ e-ISSN: 2667-7504 \\ http://ded.dem.org.tr
}

Makale Türü / Article Type:

Araştırma Makalesi / Research Article

Geliş Tarihi / Received Date: 17.05.2020

Kabul Tarihi / Accepted Date: 12.03.2021

Yayın Tarihi / Published Date: 25.06.2021

Tr/En: $\operatorname{Tr}$

Intihal / Plagiarism: Bu makale, en az iki hakem tarafindan incelendi ve intihal içermediği teyit edildi. / This article has been reviewed by at least two referees and scanned via a plagiarism software.
Atıf/Citation: Coşkun, H. \& Derse, G.E. (2021). Türkçe ders kitabındaki metinlerin değerler eğitimi açısından incelenmesi ve öğretmen görüşlerine göre değerlendirilmesi. Değerler Eğitimi Dergisi, 19 (41), s. 9-35. https://doi.org/10.34234/ded.738543 
Öz: Çalışmanın amacı Türkçe ders kitabındaki metinleri değerler eğitimi açısından incelemek ve öğretmen görüşleri bağlamında değerlendirmektir. Nitel araştırma yöntemine göre düzenlenen bu çalışmada veri toplama aracı olarak yarı yapılandırılmış görüşme ve doküman inceleme teknikleri kullanılmıştır. Çalışma dokümanı 6. sınıf Eksen Yayınları Türkçe ders kitabıdır. 10 Türkçe öğretmeni ile değer algıları ve değer aktarımında 6 . sınıf Türkçe ders kitabındaki metinler ile ilgili görüşmeler yapılmıştır. 6. sınıf Türkçe ders kitabında bulunan 40 metinde 27 değerin 247 defa geçtiği tespit edilmiştir. Metinlerde en çok rastlanan değer sorumluluk değeridir. Metinlerde estetik duyguların geliştirilmesi ve alçakgönüllülük değerlerine ise hiç rastlanmamıştır. Değerlerin en fazla yer aldığı metin türü hikâye edici metinler, en az yer aldığı metin türü ise şiirlerdir. Bilgilendirici ve hikâye edici metinlerde en fazla sorumluluk değerine, şiirlerde ise en fazla vatanseverlik değerine rastlanmıştır. Öğretmen görüşleri incelendiğinde değerler eğitimi kavramıyla ilgili öğretmenlerin en s1k bahsettiği değerler hoşgörü, sevgi ve yardımseverlik olmuştur. Öğretmenler, olumsuz olarak değerlerin eğitim boyutuyla sınırlandırılması, değerler eğitimine gerekli önemin verilmemesi ve sistemden kaynaklanan sorunlar nedeniyle değerlerin geri plânda kalması görüşlerini belirtmişlerdir. Öğretmenlerin metinlerde en çok yer verilmesini istedikleri değerin saygı değeri olduğu görülmektedir. Görüşmeler sonucunda değerlerin ders kitaplarındaki metinler aracılığıyla verilmesi gerektiği sonucuna ulaşılmıştır.

Anahtar Kelimeler: Değerler eğitimi, Türkçe dersi, Öğretmen görüşleri.

\section{$\boldsymbol{\&}$}

Abstract: The purpose of the study is to examine the texts in 6th grade Turkish coursebook in terms of values education and evaluate in context of teacher's opinions. In this research that was arranged with qualitative method, semi-structured interview and document examination methods were used for data collection. In the study as a document, Eksen Publishing 6th grade Turkish coursebook were used. Interviews with Turkish teachers were done in order to learn value perceptions of teachers and to find out their thoughts about the texts in coursebook for value transfering. In 40 texts in 6th grade Turkish coursebook, it was determined that 27 values were mentioned 247 times. Most found value was "responsibility". In the texts, "developing aesthetic feelings" and "modesty" values could never be seen. The type of the texts that has most values was stories, the least ones were poems. In informative and story type texts, most 
used value was "responsibility", in poems, it was "patriotism". When teachers views were examined, most values coming to mind of teachers were "tolerance, "love" and "charity". Teachers also stated some negative opinions. Those are "values limited only in education" "not caring values education enough" and "ignoring values due to systematical problems." It was seen that teachers want the value "respect" most that should be included in texts. As a result of interviews, values should be given via the texts in coursebooks.

Keywords: Values education, Turkish lesson, Teacher opinions.

(The Extended Abstract is at the end of the article)

\section{Giriş}

Son y1llarda ön plana çıkan yeni düşünceler ve yapılan tartışmalar eğitimin asıl amacının öğrencinin bilişsel becerilerini geliştirmekten çok daha fazlası olduğunu göstermektedir. Eğitim, bireyleri kendini meydana getiren değerlerden kopmayan ve bu değerleri gelecek nesillere taşıyan; düşünce ve karakter olarak gelişime açık bir kimliğe büründürmek gayesindedir. Bu gaye, toplumu amaçlanan çağdaş medeniyetler seviyesine ulaştırmada önemli bir yapı taşıdır. Toplumun amaçlanan çağdaş medeniyetler seviyesine ulaşması için de toplumu oluşturan bireylerin değer olarak belli davranışları kabul etmeleri gerekmektedir.

Değerler insanların nasıl davranacaklarını belirleyen, insanları iyiye, güzele yönlendiren, bireyi ve toplumu kalkındıran unsurlardır. Bu açıdan bakıldığında değerler ve değerler eğitimi eğitim-öğretim sürecinde büyük önem taşımaktadır (Çakıroğlu, 2013, s. 6). Değerler eğitiminin eğitim-öğretim sürecinde sağlıklı kararlar verebilen, sağlıklı davranışlar sergileyen ve pozitif duygular hisseden insanların topluma kazandırılması gibi hedefleri olduğu görülmektedir. Değerler eğitiminin başka bir amacı da insanın doğuştan gelen niteliklerini açığa çıkarmak ve kişiliğini geliştirmektir. Bunun yanında bireyin iyiye, doğru olana ulaşmasına yardım etmek, kötü ahlâktan insanları ve toplumu korumak değerler eğitiminin amaçları arasındadır (Kızıler ve Canikli, 2016, s. 21). Bu amaçlara ulaşmak insanı değerli kılar. İnsanların değerlerin farkında olması, değerleri kazanması ve kazandığı değerleri kişiliğinin yapı taşları haline getirerek davranışa dönüştürmesi bireylerin gelecekteki kişiliğini, davranışlarını, yaşamlarını belirleyecek unsurlar olduğu için gerekmektedir. Ömür boyu devam eden bu sürece de değerler eğitimi denilmektedir (Yaman, 2016, s. 18). Değerler eğitimi, eğitim-öğretim sürecinin en alt basamağından başlayarak en üst basamağına kadar tüm kademelerde programlı bir şekilde verilmektedir. 
Öğrencilere bilgi, beceri, davranışlar kazandırmak, toplumun yaşam kalitesini ve refahını yükseltmek, eğitimi kitlelere ulaştırmak, gelecek kuşaklara toplumun kültürünü ve değerlerini aktarmak yoluyla toplumun sürekliliğini sağlamak ilköğretimin amaçları arasındadır (1739 Sayılı Milli Eğitim Temel Kanunu, 1973). İlköğretimin bu amaçları doğrultusunda değerler, örgün eğitim kurumları için oluşturulan programlar yoluyla bir plân dâhilinde öğrencilere kazandırılmaktadır. Türkçe dersi öğretim programı da bu amaca hizmet etmektedir. Türkçe dersi etkili dinlemeyi, doğru ve standartlara uygun konuşmayı, dil bilgisi kurallarını öğretmeyi, güzel okumayı ve yazmayı; bunun yanında öğrencinin milli, ahlâki, sosyal ve evrensel değerleri kazanmasını da hedefler (Doğan ve Gülüşen, 2011, s. 77). Türkçe dersi insanların diğer insanlarla sağlıklı iletişim kurmasını ve dil becerilerini kazanmasını sağlamakla birlikte evrensel ve toplumsal değerleri de kazandırmalıdır. Kendi kültürünü ve ana dilini Türkçe dersinde öğrenen bireyin bu öğrenmeler yoluyla içerisinde yaşadığ 1 toplumun sahip olduğu değerler konusunda farkındalığı artacaktır. Bu nedenle değerler eğitiminin Türkçe dersi içerisinde verilmesi oldukça önemlidir.

Türkçe dersinde ana materyal olarak ders kitapları kullanılır. Ders kitapları öğrencinin yaşına ve bilgi düzeyine uygun, bilişsel ve duyuşsal becerilerle zenginleştirilmiş metinlerden oluşan, öğretim programlarının temel ilkelerine uygun bir biçimde oluşturulan, içinde barındırdığı bilgileri öğretmen vasıtasıyla öğrencilere ileten, yazılı eğitim-öğretim materyalleridir (Çeçen ve Çiftçi, 2007, s. 39). Ders kitapları eğitim-öğretim ortamın belirleyen önemli araçlardır. Öğrencilerin zihinsel tasarımlarının oluşumu, okuma alışkanlığı kazanması vb. birçok yaşam faaliyeti ders kitaplarıyla biçimlenmektedir (Yapıcı, 2004, s. 122). Program ile öğrenci arasında bir köprü işlevi gören (Ataman, 2001) ders kitaplarının amacına ulaşabilmesi öğretmenlerin etkili bir şekilde onu kullanabilmesiyle olur. Ama öncelikli olarak bu ders kitaplarının öğrencinin bilişsel, duyuşsal ve fiziksel niteliklerine ve değerlere uygun bir şekilde yapılandırılmas1 gereklidir.

Görüldüğg̈ üzere derslerin ana materyali olan ders kitapları ve bu kitaplarda bulunan metinler değer eğitiminde yararlanılan en önemli kaynaklardandır. Ders kitaplarının kurgusu değer eğitimini sağlayacak ve bu eğitimi kazandırabilecek bir donanıma sahip olmalıdır. Değerleri kazandırırken en etkili yol Türkçe ders kitaplarında bulunan metinlerdir (Doğan ve Gülüşen, 2011, s. 76). Ana dili öğretiminde ana materyal olarak kullanılan metinlerin değer aktarımında önemi yadsınamaz bir gerçektir (Özbay ve Karakuş Tayşi, 2011, s. 24). Dolayısıy- 
la yeni nesillere metinler aracılığıyla değerler aktarımı yapılacağından Türkçe ders kitaplarına metin seçerken çok özenli çalışılmalıdır (Doğan ve Gülüşen, 2011, s. 78). Çünkü Türkçe ders kitaplarındaki metinler, öğrencilere değerleri edindirmek için yapılacak etkinliklere yol göstericidir (Kaygana, Yapıcı ve Aytan, 2013, s. 658). Metinler, değerlerin gelecek nesillere aktarımında da bir köprü vazifesi görmektedir. Türkçe derslerinde çeşitli bilgi ve becerileri kazandırırken farklı türlerdeki edebi metinler araç olarak kullanılmaktadır (Fırat ve Mocan, 2014, s. 28). Öğrenciler ders kitaplarında karşılaştıkları bu farklı türdeki metinler vasıtasıyla farklı sosyal rollerle karşılaşmaktadır. Ayrıca bu metinlerde bulunan evrensel değerlerin aktarılması yoluyla iyiyle kötüyü ayırt edebilmekte, doğru davranmayı ve düşünmeyi öğrenmektedir (Çelikpazu ve Aktaş, 2011). Bu yüzden ders kitaplarında bulunan metinler gerçek hayatla uyumlu, okunabilir, yorumlanabilir ve anlaşılır olmalıdır (Coşkun ve Sargın, 2007). Metinler aracılığı ile değer aktarımı yapılırken içinde bulunduğumuz yüzyılın şartları göz önünde bulundurulmalı, öğrencilere kazandırılmak istenen değerler günümüz ihtiyaçları göz önüne alınarak belirlenmelidir. İçinde bulunduğumuz yüzyılın bireylere kazandırmayı amaçladığı temel becerilerin başında manevi, milli ve evrensel değerlere karşı hassas olma, sosyal ve bireysel değerlere önem verme becerileri gelmektedir (Yaman, Taflan ve Çolak, 2009, s. 108). Özetle metinlerin değerler eğitimindeki önemi Türkçe ders kitaplarının içeriğinin değerlerden uzak kalamayacağının göstergesidir. Bu içerikteki en önemli yapı taşı da şüphesiz metinlerdir. Metinlerin de bireylere ulusal ve evrensel boyutta değerleri kazandıracak içeriklerle donatılmış olması gerekli hatta zorunludur.

Gerek Türkçe Dersi Öğretim Programı gerek yapılan çalışmalar incelendiği zaman değerler eğitiminin çok önemli bir yerinin olduğu görülmektedir. Değerler eğitimi sevgi, sayg1, dürüstlük, hoşgörü, sorumluluk gibi evrensel değerlere vurgu yapar. Öğrencilerin bu değerlerin önemini kavramalarını ve bu değerlere yaşantılarında yer vermelerini amaçlar. Bu yüzden, okulda değerler mutlaka kazandırılmalı ve bu konunun öneminin farkında olunmalıdır. Türkçe dersiyle ilgili değerler eğitimi üzerine yapılan çalışmalara bakıldığında Doğan ve Gülüşen (2011)'in 6, 7 ve 8. sinıf Türkçe ders kitaplarındaki değerleri incelediğii; Atalay (2013)'ın 2012-2013 öğretim yılı ilköğretim 6. sınıf Türkçe ders kitaplarında yer alan "sevgi" ve "duygular" temalarını değerler eğitimi açısından incelediği; Fırat ve Mocan (2014)'ın Türkçe ders kitaplarındaki hikâyelerde yer alan değerleri incelediği; Gül (2017)'ün 5. sınıf Türkçe ders kitabını değerler eğitimi yaklaşımıyla incelediği görülmektedir. Alanda yapılan çalışmalara bakıldığında ders kitaplarındaki metinleri ve öğretmen görüşlerini bir araya getiren bir çalışmanın gerekli olduğu görülmektedir. 
Dolayısıyla bu çalışma, 2018-2019 eğitim-öğretim yılında okutulan 6. sınıf Eksen yayınları Türkçe ders kitabındaki metinlerin değerler eğitimi açısından incelenmesi ve öğretmen görüşleri bağlamında değerlendirilmesini amaç edinmiştir. Bu ana amaç kapsamında ele alınmış alt amaçlar şu şekildedir:

- 6. sınıf Türkçe ders kitabındaki (Eksen Yay.) metinlerde yer alan değerleri, bu değerlerin temalara göre dağılımını ve hangi tür metinlerde sıklaştığını belirlemek,

- Öğretmenlerin değer algılarını belirlemek ve metinleri ilettiği değerler açısından öğretmen görüşlerine göre değerlendirmektir.

\section{Yöntem}

Nitel araştırma yöntemine göre tasarlanan bu çalışmada doküman incelemesi ve görüşme yapılarak veriler toplanmıştır. Var olan bir durumun bütüncül bir bakış açısıyla ve derinleştirilerek incelenmesi amaçlandığından nitel araştırma yöntemi tercih edilmiştir. Bu bağlamda doküman incelemesi yapılarak Türkçe ders kitaplarında yer alan metinler ilettiği değerler açısından detaylı bir şekilde incelenmiştir. Buna ek olarak görüşmeler aracıllı̆ııla Türkçe öğretmenlerinin Türkçe ders kitaplarındaki metinleri ilettiği değerler açısından değerlendirmeleri ve kendilerinin değer algılarının neler olduğu ortaya konulmaya çalışılmıştır.

\section{Çalışma Grubu ve Çalışma Dokümanı}

Çalışma dokümanı olarak 6. sınıf Eksen yayınları Türkçe ders kitabında (20182019) yer alan 40 metin kullanılmıştır. Eksen yayınları ders kitabının tercih edilme sebebi metinlerle ilgili görüşme yapılması planlanan Türkçe öğretmenlerinin görev yaptığı Bitlis ilinde ilgili tarihlerde bu kitabın Türkçe derslerinde kullanılıyor olmasıdır. Görüşme yapılan çalışma grubunun belirlenmesinde ise araştırmacının katılımcılara kolay ulaşması ve veri toplama sürecini sağlıklı yürütmesi amacıyla uygun örnekleme (kolay ulaşılabilir) yöntemi tercih edilmiştir. Bu nedenle çalışma grubunu Bitlis ili ortaokullarında görev yapan 10 Türkçe öğretmeni oluşturmuştur. Farklı okullarda görev yapan öğretmenleri çalışmaya katmak amacıyla her okuldan çalışmaya gönüllü olarak katılmayı kabul eden 1 Türkçe öğretmeni ile görüşme yapılmıştır. Katılımcıların 5'i kadın, 5'i erkektir. 8 öğretmen 0-5 yıl arası mesleki deneyime sahipken 2 öğretmen 6-10 yıl arası mesleki deneyime sahiptir. 


\section{Veri Toplama Araçlarının Geliştirilmesi, Verilerin Toplanması ve Veri Analizi}

Araştırmada veri toplama aracı olarak doküman incelemesi ve yarı yapılandırılmış görüşme formu kullanılmıştır.

Doküman incelemesi sürecinde ilk aşamada 6. sınıf Eksen yayınları Türkçe ders kitabında (2018-2019) bulunan metinlerdeki değerleri incelemek üzere MEB Değerler Eğitimi Yönergesi’nde (2018) verilen 27 değer listelenmiştir. Bu listeden hareketle Türkçe ders kitabındaki her bir metin ilettiği değerler açısından incelenmiştir. Analiz yapılırken cümle birimleri dikkate alınmış, bir değerin metinde kaç kez geçtiği tespit edilmeye çalışılmıştır. Buna göre bir metinde bir değerin metnin farklı bölümlerinde farklı sayılarda geçtiği görülmüştür. Doküman incelemesinin güvenirliği için kodlayıcı güvenirliği yapılmıştır. Türkçe ders kitabının 1. temasındaki toplam 5 metin iki araştırmacı tarafından ayrı ayrı kodlanmıştır. Miles ve Huberman (1994) güvenirlik formülüne göre \%80 oranında kodlayıcı tutarlılığı sağlanmıştır. Uyum sağlanamayan kısımlar için iki kodlayıcı analizi yeniden yapmış, uyum sağlandıktan sonra bir kodlayıcı analize devam etmiştir. Her metnin detaylı bir şekilde analiz edilmesinden sonra bu değerler belirlenmiş ve temalara göre yeni bir tasnife tabi tutulmuştur. Bu tasnif sonucunda en çok hangi değerlerle karşılaşıldığ 1 ve değerlerin hangi temalarda yoğunlaştığı ortaya çıkmıştır. Bir sonraki aşamada değerler metin türlerine göre ayrıca incelenmiştir.

Yarı yapılandırılmış görüşme formunun hazırlanmasında araştırmanın amacına uygun olarak soru havuzu oluşturulmuş, araştırmanın amacına hizmet ettiği düşünülen sorular bu havuzdan çekilmiş ve taslak bir form oluşturulmuştur. Taslak form ile ilgili Türkçe eğitimi alanında öğretim üyesi olan uzmanların görüşü alınmış ve uzmanlardan gelen dönütler ve pilot uygulama neticesinde görüşme formunda 11 soruya yer verilmesi uygun görülmüştür. Veri toplama sürecinde 10 gönüllü Türkçe öğretmeninden çalışmaya konu olan Türkçe ders kitabındaki 40 metni okuyup değerler açısından incelemeleri istenmiştir. Daha sonra öğretmenlerle görüşmeler yapılmış, görüşme ses kayıtları yazıya dökülmüş ve veri analizi sürecine geçilmiştir. Verilerin analizinde içerik analizi yapılmıştır. Veriler kodlama, kod birleştirme ve temalaştırma aşamalarına göre analiz edilmiştir. Analiz güvenirliği için kodlayıcılar arası uyuma bakılmıştır. Kodlama işleminin güvenirliğini sağlamak için tesadüfi olarak örneklemin \%10'unu temsil eden 1 kişiye ait görüşme formu iki kodlayıcı tarafından ayrı ayrı kodlanmıştır. Kodlayıcılar bağımsız olarak kodlama işlemini bitirdikten sonra bir araya gelinmiş ve 
kodlamalar karşılaştırılmıştır. Kodlardaki benzerlikler ve farklılıklar tartışılmış ve kodlayıcılar arasında görüş birliği sağlandığı için kodlayıcılardan biri analize devam etmiştir. Analiz sürecinde kodlama yapan araştırmacılar ihtiyaç duyuldukça bir araya gelmiş ve kodlamalar üzerinde fikir alışverişinde bulunmuşlardır. Veri analizi tamamlandıktan sonra kodlar kategorileştirilmiş, görüşme sorularından hareketle belirlenmiş olan temalar altında sunulmuş ve katılımcı görüşleriyle örneklendirilmiştir.

Etik izin: Van Yüzüncü Yıl Üniversitesi Sosyal ve Beşeri Bilimleri Yayın Etik Kurulu'nun 13.05.2020 tarih ve 2020/03-02 sayılı kararı gereği çalışmanın uygulanmasının etik açıdan bir sorun teşkil etmediği görülmüştür.

\section{Bulgular}

Bu bölümde Türkçe ders kitabındaki metinlerde en çok hangi değerlerin yer aldığı, bu değerlerin hangi temalarda ve hangi tür metinlerde yoğunlaştı̆̆ ortaya konulmuştur. Ayrıca Türkçe öğretmenlerinin değer algıları belirlenmiş ve değerlerle ilgili ders kitaplarındaki metinlere dair değerlendirmelerine yer verilmiştir.

\section{Değerlerin Temalara Göre Dağılımının İncelenmesine Dayalı Bulgular}

Türkçe ders kitaplarındaki değerler temalara dağılımı açısından incelenmiş, ilgili sonuçlar aşağıdaki tabloda sunulmuştur.

Değerler

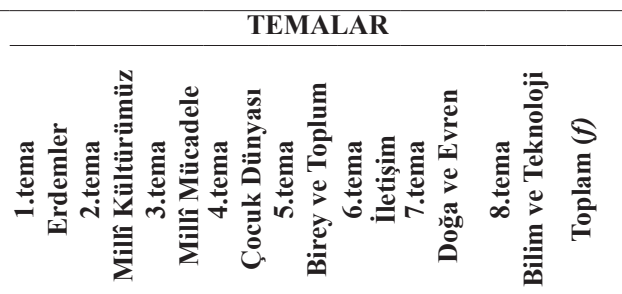

\begin{tabular}{lccccccccc}
\hline Sevgi & - & 4 & 4 & 1 & 1 & 4 & 6 & - & $\mathbf{2 0}$ \\
\hline Sorumluluk & 7 & - & 2 & 1 & 5 & 5 & 5 & 1 & $\mathbf{2 6}$ \\
\hline Saygi & 2 & 3 & 1 & 5 & 4 & 4 & - & 1 & $\mathbf{2 0}$ \\
\hline Hoşgörü-Duyarlılık & 1 & 2 & - & 2 & 3 & 4 & 2 & - & $\mathbf{1 4}$ \\
\hline Özgüven & - & - & - & 1 & - & - & - & - & $\mathbf{1}$ \\
\hline Empati & - & - & - & 1 & - & 1 & - & - & $\mathbf{2}$ \\
\hline Adil Olma & 2 & - & - & 1 & - & 1 & - & - & $\mathbf{4}$ \\
\hline Cesaret-Liderlik & 5 & - & 5 & - & - & 1 & 1 & 1 & $\mathbf{1 3}$ \\
\hline Nazik Olmak & 1 & 2 & - & 1 & 1 & 1 & 2 & 1 & $\mathbf{9}$ \\
\hline Dostluk & 11 & - & - & 1 & - & - & - & - & $\mathbf{1 2}$ \\
\hline Yardimlaşma Dayanıșma & 5 & 1 & 2 & 1 & 2 & 1 & - & 2 & $\mathbf{1 4}$ \\
\hline
\end{tabular}




\begin{tabular}{lccccccccc}
\hline Temizlik & - & 1 & - & - & 4 & 1 & 2 & - & $\mathbf{8}$ \\
\hline Doğruluk-Dürüstlük & 5 & - & - & - & - & 6 & - & - & $\mathbf{1 1}$ \\
\hline Aile Birliğine Önem Verme & - & - & - & 1 & - & 2 & 1 & 1 & $\mathbf{5}$ \\
\hline Bağımsız ve Özgür Düşünebilme & 2 & - & 2 & - & 2 & 1 & - & 2 & $\mathbf{9}$ \\
\hline İyimserlik & 1 & - & - & - & - & - & - & - & $\mathbf{1}$ \\
\hline Estetik Duyguların Geliştirilmesi & - & - & - & - & - & - & - & - & - \\
\hline Misafirperverlik & 1 & 2 & - & 2 & 1 & - & - & - & $\mathbf{6}$ \\
\hline Vatanseverlik & 7 & 1 & 13 & - & - & - & - & - & $\mathbf{2 1}$ \\
\hline İilik Yapmak & 8 & 1 & - & 1 & - & - & 3 & 1 & $\mathbf{1 4}$ \\
\hline Çalışkanlık & - & - & 3 & - & 1 & - & - & 3 & $\mathbf{7}$ \\
\hline Paylaşımcı Olmak & 1 & - & - & - & 5 & 1 & - & 1 & $\mathbf{8}$ \\
\hline Şefkat Merhamet & - & - & - & - & - & - & 2 & - & $\mathbf{2}$ \\
\hline Selamlaşma & - & 1 & - & 1 & 1 & - & - & - & $\mathbf{3}$ \\
\hline Alçakgönüllü̈lük & - & - & - & - & - & - & - & - & - \\
\hline Fedâkarlık & 4 & 1 & - & 1 & - & - & - & - & $\mathbf{6}$ \\
\hline Kültürel Mirasa Sahip Çıkma & 1 & 5 & 2 & 2 & - & 1 & - & - & $\mathbf{1 1}$ \\
\hline Toplam $(f)$ & $\mathbf{6 4}$ & $\mathbf{2 4}$ & $\mathbf{3 4}$ & $\mathbf{2 3}$ & $\mathbf{3 0}$ & $\mathbf{3 4}$ & $\mathbf{2 4}$ & $\mathbf{1 4}$ & $\mathbf{2 4 7}$ \\
\hline
\end{tabular}

Tabloya bakıldığında 6. sınıf Eksen yayınları Türkçe ders kitabında 8 tema, bu temalar içerisinde 40 metin olduğu görülmektedir. Metinlerde en çok yer alan değer sorumluluk değeri olarak tespit edilmiştir. Bunu takiben vatanseverlik, sevgi ve saygı değerleri gelmektedir. Estetik duyguların geliştirilmesi ve alçakgönüllülük değerlerine metinlerde rastlanmamıştır. İyimserlik ve özgüven değerlerine de sadece $1 \mathrm{kez}$ rastlanmıştır.

Ayrıca değerlerin en çok yer aldığı temanın 64 frekansla Erdemler teması, değerlerin en az yer aldığı temanın ise 14 frekansla Bilim ve Teknoloji teması olduğu görülmektedir. Temalarda toplam 247 defa değer tespit edilmiştir. 2, 4 ve 7. temalardaki değer sayıları birbirine yakındır.

\section{Değerlerin Hangi Tür Metinlerde Sıklaştığının İncelenmesine Dayalı Bulgular}

Türkçe ders kitaplarındaki değerlerin metin türlerine göre genel dağılımı incelenmiş, ilgili sonuçlar aşağıdaki tabloda sunulmuştur.

\begin{tabular}{lllll}
\hline Tablo 2: Değerlerin Metin Türlerine Göre Dağlımı & $\begin{array}{l}\text { Siir Türü } \\
\text { Bilgilendirici } \\
\text { Metinler } \\
\text { Toplam Değer }(f)\end{array}$ & $\begin{array}{l}\text { Hikâye Edici } \\
\text { Metinler } \\
\text { Toplam Değer }(f)\end{array}$ & $\begin{array}{l}\text { Toplinler } \\
(f)\end{array}$ & $\begin{array}{l}\text { Toplam Değer } \\
(f)\end{array}$ \\
\hline Sevgi & 5 & 8 & 7 & $\mathbf{2 0}$ \\
\hline Sorumluluk & 11 & 11 & 4 & $\mathbf{2 6}$ \\
\hline Sayg1 & 10 & 3 & 7 & $\mathbf{2 0}$ \\
\hline Hoşgörü-Duyarlı1ık & 7 & 4 & 3 & $\mathbf{1 4}$ \\
\hline Özgüven & - & 1 & - & $\mathbf{1}$ \\
\hline Empati & 1 & - & 1 & $\mathbf{2}$ \\
\hline
\end{tabular}


Türkçe Ders Kitabındaki Metinlerin Değerler Eğitimi Açısından İncelenmesi ve ...

\begin{tabular}{|c|c|c|c|c|}
\hline Adil Olma & 2 & 2 & - & 4 \\
\hline Cesaret-Liderlik & 4 & 8 & 1 & 13 \\
\hline Nazik Olmak & 3 & 6 & - & 9 \\
\hline Dostluk & 4 & 8 & - & 12 \\
\hline Yardımlaşma-Dayanışma & 3 & 11 & - & 14 \\
\hline Temizlik & 5 & 1 & 2 & 8 \\
\hline Doğruluk-Dürüstlük & 6 & 5 & - & 11 \\
\hline $\begin{array}{l}\text { Aile Birliğine Önem } \\
\text { Verme }\end{array}$ & 2 & 3 & - & 5 \\
\hline $\begin{array}{l}\text { Bağımsız ve Özgür Düşü- } \\
\text { nebilme }\end{array}$ & 5 & 4 & - & 9 \\
\hline İyimserlik & - & 1 & - & 1 \\
\hline $\begin{array}{l}\text { Estetik Duyguların Geliş- } \\
\text { tirilmesi }\end{array}$ & - & - & - & - \\
\hline Misafirperverlik & - & 6 & - & 6 \\
\hline Vatanseverlik & 1 & 9 & 11 & 21 \\
\hline İyilik Yapmak & 2 & 7 & 5 & 14 \\
\hline Çalışkanlık & 3 & 4 & - & 7 \\
\hline Paylaşımcı Olmak & 2 & 2 & 4 & 8 \\
\hline Şefkat-Merhamet & - & 2 & - & 2 \\
\hline Selamlaşma & - & 3 & - & 3 \\
\hline Alçakgönüllülük & - & - & - & - \\
\hline Fedakarlık & 1 & 5 & - & 6 \\
\hline $\begin{array}{l}\text { Kültürel Mirasa Sahip } \\
\text { Çıkma }\end{array}$ & 8 & 2 & 1 & 11 \\
\hline Toplam $(f)$ & 85 & 116 & 46 & 247 \\
\hline
\end{tabular}

Yukarıdaki tabloda metin türlerine göre değerler incelediğinde hikâye edici metin türünde değerlere daha fazla yer verildiği görülmektedir. Tabloya göre değerlere en az yer verilen metin türü şiirdir.

Bilgilendirici metin türünde en sık rastlanan değerin sorumluluk değeri olduğu görülmektedir. Özgüven, iyimserlik, estetik duyguların geliştirilmesi, misafirperverlik, şefkat-merhamet, selamlaşma, alçakgönüllülük değerlerine ise bilgilendirici metinlerde rastlanmamaktadır. Hikâye edici metin türünde en sık rastlanan değerler ise sorumluluk ve yardımlaşma-dayanışma değerleridir. Empati, estetik duyguların geliştirilmesi ve alçakgönüllülük değerlerine ise hikâye edici metin türünde rastlanmamıştır. Tabloya göre şiirlerde en sık rastlanan değerin vatanseverlik olduğu görülmektedir.

Öğretmenlerin Değer Algılarının Belirlenmesine ve Metinlerin İlettiği Değerler Açısından Öğretmen Görüşlerine Göre Değerlendirilmesine Dayalı Bulgular

$\mathrm{Bu}$ bölümde çalışmaya katılan öğretmenlerin değer algıları belirlenmiş ve 6.sınıf Türkçe ders kitabındaki değerlerle ilgili değerlendirmelerine yer verilmiştir. Aşağıdaki tabloda değerler eğitimi kavramılla ilgili öğretmenlerin algıları yer almaktadır. 


\begin{tabular}{ll}
\hline \multicolumn{2}{l}{ Tablo 3: Değerler Eğitimi Kavramıyla İlgili Öğretmenlerin Algıları } \\
\hline Kategoriler & Kodlar ( $f$ ) \\
\hline \multirow{2}{*}{ Değerler } & $\begin{array}{l}\text { Yardımseverlik (5), sevgi (4), hoşgörü (4), vatanseverlik (3), saygı } \\
\text { (3), insaniyet (2), iyilik (2), adalet (1), misafirperverlik (1), dürüstlük } \\
\text { (1), paylaşımcı olmak (1), dostluk (1) }\end{array}$ \\
\hline \multirow{3}{*}{ Tanımlar ve Amaçlar } & $\begin{array}{l}\text { İyi insan yetiştirme (4), tarihsel ve evrensel olma (3), dini inançlar } \\
\text { (1), toplumsal yaşayış biçimleri (1), insanların birbirleriyle uyum } \\
\text { içinde olması (1), huzurlu bir ortam oluşturma (1), toplumun üzerinde } \\
\text { uzlaştı̆̆ davranışlar (1), insanların hayattan beklentileri (1) }\end{array}$ \\
\hline \multirow{2}{*}{ Değerlerin Kazandırılma } \\
Şekli & $\begin{array}{l}\text { Değerlerin eğitimin içinde verilmesi (3), değer aktarımında rol model } \\
\text { olunması (2), Değerlerin oluşmasında sosyal çevrenin, ailenin, öğret- } \\
\text { menin, yaşın ve kişilik özelliklerinin etkisi (1), değerler eğitiminin } \\
\text { okullarda verilmesi (1), çeşitli yöntem ve tekniklerin kullanılması (1), } \\
\text { değerlerin öğretimin içinde verilmesi (1) }\end{array}$ \\
\hline
\end{tabular}

Tablo incelendiğinde çalışmaya katılan öğretmenlerin değerler eğitimi kavramıyla ilgili akıllarına en çok gelen değerlerin hoşgörü, sevgi ve yardımseverlik olduğu görülmektedir. Öğretmenlerin değerler eğitimi ile ilgili yaptıkları tanım ve amaç cümleleri incelendiğinde iyi insan yetiştirme, tarihsel ve evrensel olma kavramları üzerinde durulmaktadır. Ayrıca değerlerin kazandırılma şekliyle ilgili öğretmenlerin görüşleri incelendiğinde değerlerin eğitimin içinde verilmesi ve değerleri aktarırken rol model olunması görüşleri ön plâna çıkmaktadır. $\mathrm{Bu}$ konuya Ö5 kodlu öğretmenin görüşü örnek verilebilir:

"Çocukları insani yönden geliştirmek geliyor. Onlara bir şeyler katmak sürekli öğretim yönünden düşünmek değil de biraz da eğitsel yönden yönlendirmek geliyor." (Ö5)

Çalışmaya katılan öğretmenlere değerlerin eğitim öğretimdeki yeri ile ilgili soru yöneltilmiştir. Öğretmenlerin bu konudaki görüşleri Tablo 4'te yer almaktadır.

Tablo 4:Değerlerin Eğitim Öğretimdeki Yeriyle İlgili Öğretmenlerin Algıları

\section{Kategoriler $\operatorname{Kodlar}(f)$}

Değerlerin ders kitaplarındaki metinler aracılığıyla verilmesi (5), değerlerin eğitimin vazgeçilmez unsuru olması (3), değerler eğitiminin bilinçli ve programlı bir şekilde veOlumlu rilmesi (2), etkinlikler yoluyla değerleri aktarmak (2), değer aktarımında ögretmenlerin Görüsşer işbirliği içerisinde bulunması (2), öğrencilerin farkında olmadan değerleri benimsemesi (1), değer aktarımında sözel derslerin uygunluğu (1), geleceğe yön vermesi (1), değerlerin kazanım haline gelmiş olması (1), değerlerin evrenselliği (1), değerler eğitiminin öğrenciler tarafından sevilmesi (1), değerlerin eğitim-öğretim yoluyla aktarılması (1)

Değerlerin eğitim boyutuyla sınırlandırılması (4), değerler eğitimine gerekli önemin verilmemesi (3), sistemden kaynaklanan sorunlar nedeniyle değerlerin geri plânda

Olumsuz kalması (3), müfredatta yeteri kadar yer verilmemesi (2), değerlerin benimsenmemesi

Görüşler (1), değerlerin müfredatla sınırlı kalması (1), değerler eğitimine öğretmenlerin gereken önemi vermemesi (1)

Aile, toplum ve okulun değerleri benimsetme sorumluluğu (2), değerlerin diğer derslerin müfredatında da yer alması gerekliliği (2), aylık değer uygulaması (1), değerlerin farklı dersler aracılığıyla aktarılması (1), seçilen metin ve etkinliklere önem verilmesi

Yapılması

Gerekenler (1), okul atmosferine değerlerin yayılması (1), değer aktarımında aile-öğretmen-öğrenci işbirliği (1), öğretmenlerin rol model alınması (1), Türkiye geneli sınavlarda değerlerin yer alması (1), değerlerin sosyal projeler yoluyla aktarılması (1) 
Değerlerin eğitim-öğretimdeki yeriyle ilgili öğretmenlerin algıları incelendiğinde çalışmaya katılan 5 öğretmenin değerlerin ders kitaplarındaki metinler aracılığıyla verilmesi ile ilgili olumlu görüş bildirdiği görülmektedir. Değerlerin eğitimin vazgeçilmez unsuru olduğuna da 3 öğretmen tarafından değinilmektedir. Çalışmaya katılan öğretmenlerin olumsuz olarak en sık söylediği görüşler: değerlerin eğitim boyutuyla sınırlandırılması, değerler eğitimine gerekli önemin verilmemesi ve sistemden kaynaklanan sorunlar nedeniyle değerlerin geri plânda kalması olmuştur. Yapılması gerekenlere de değinen öğretmenler; aile, toplum ve okulun değerleri benimsetme sorumluluğu ve değerlerin diğer derslerin müfredatında da yer alması gerektiği üzerinde durmaktadırlar.

Değerlerin eğitim öğretimdeki yeriyle ilgili öğretmen görüşlerini yansıtan örnek şöyledir:

Ö6: "Bence değerler eğitimi bizim müfredatta verdiğimiz diğer şeylerden daha önemli. Biz çoğu zaman boşa kürek sallyyor gibi dil bilgisi, şu kazanımı verdim mi, bu konuyu verdim mi? Onun tereddütüne düşüyoruz. Benim açımdan değerler ĕgitimi onlardan daha değerli. Onlar verilmesin demiyorum ama onlardan daha değerli."

Öğretmenlere ders planlarında değerlerin kazanım olarak yer verilmesinin gerekliliği ile ilgili soru yöneltilmiştir. Öğretmenlerin bu konudaki görüşlerine ilişkin bulgular aşağıda yer almaktadır.

Tablo 5: Değerler Eğitimine Ders Plânlarında Kazanım Olarak Yer Verilmesi İle İlgili Öğretmenlerin Görüşleri

\begin{tabular}{|c|c|}
\hline Kategori & Kodlar $(f)$ \\
\hline $\begin{array}{l}\text { Evet ve Ne- } \\
\text { denleri }\end{array}$ & $\begin{array}{l}\text { Öğretmen açısından farkındalığı arttırmalı (4), değerler eğitimi müfredata yedirilerek } \\
\text { verilmeli (3), Türkçe derslerinde değerler metinler aracıllğıyla verilmeli (2), değerler } \\
\text { eğitimine yeterli zamanı ayrılabilmeli (2), öğretmenler değerlerle ilgili derse hazırlıklı } \\
\text { gelmeli (2), öğretmen değerleri kazandırmada sorumluluk hissetmeli (2), değerler } \\
\text { sezdirme yoluyla verilmeli (1), değerler eğitimine programda verilen önem arttırılmalı } \\
\text { (1), değerlere gereken önem verilmeli (1), değerler eğitimi okulda verilmeli (1) }\end{array}$ \\
\hline
\end{tabular}

Hayır ve Somut olarak gözlenememesi (1), ders içinde çeşitli yöntem ve tekniklerle değer Nedenleri aktarımının yapılması (1)

Çalışmaya katılan öğretmenlere sorulan "Değerler eğitimine ders plânlarında kazanım olarak yer verilmeli midir?” sorusuna öğretmenlerin önemli ölçüde evet cevabını verdiği görülmektedir. Bu düşüncelerini çoğunlukla öğretmen açısından farkındalığı arttırmalı ve değerler eğitimi müfredata yedirilerek verilmeli ifadeleriyle desteklemektedirler. Hayır cevabını veren öğretmenler ise bunun nedenini somut olarak gözlenememesi ve ders içinde çeşitli yöntem ve tekniklerle değer aktarımının yapılması olarak belirtmişlerdir. Öğretmenlerin görüşlerine örnek şöyledir: 
"Değerler eğitimi kazanım şeklinde olsa daha iyi olur. En azından öğretmen bu kazanımı işlemek zorunda olduğu için daha yararlı olur. Yeterli zamanı değerler eğitimine ayırabilir. Değerler ile ilgili derse hazırlıklı gelebilir." (Ö8)

Öğretmenlere Türkçe derslerinde değerleri öğrencilere aktarmada hangi yollara başvurdukları sorulmuştur. Öğretmenlerin görüşlerine ilişkin bulgular Tablo 6 'da yer almaktadir.

Tablo 6: Türkçe Derslerinde Değerleri Öğrencilere Aktarmak İçin Öğretmenlerin Başvurduğu Yollar

\begin{tabular}{ll}
\hline Kategori & Kodlar $(f)$ \\
\hline \multirow{2}{*}{$\begin{array}{l}\text { Illişkilendirme } \\
\text { Konu ve metin aracılığıyla açı̆̆a çıkarma (6), güncel olaylarla örneklendirme (3), } \\
\text { etkinlikler yoluyla değerleri aktarma (2), somut yaşamla ilişkilendirme (2), ana } \\
\text { fikri sorarak değeri buldurma (2), aile ve sosyal çevreyle ilişkilendirerek verme } \\
\text { (1), okul ikliminde değerleri aktarma (1) }\end{array}$} \\
$\begin{array}{l}\text { Yöntem ve Tek- } \\
\text { nikler }\end{array}$ & $\begin{array}{l}\text { Canlandırma (5), tartışma (3), soru-cevap (3), münazara (2), rol yapma (2), zıt } \\
\text { tepki (1) anlatma (1), grup çalışması (1), öğrenci araştırmaları (1), eğitsel oyunlar }\end{array}$ \\
\hline
\end{tabular}

Çalışmaya katılan öğretmenlerle yapılan görüşmeler incelendiğinde Türkçe derslerinde değerleri öğrencilere aktarmak için ilişkilendirme ve yöntem-tekniklere başvurdukları görülmektedir. İlişkilendirmede konu ve metin aracılığıyla ön plâna çıkarma ve güncel olaylarla örneklendirme yolları öne çıkmaktadır. En çok kullandıkları yöntem ve tekniklerin canlandırma, soru-cevap ve tartışma olduğu görülmektedir. Öğretmen görüşlerine örnek şöyledir:

Ö2: "Okuma metinlerinde zaten değerler metnin içinde gizil bir şekilde veriliyor. Biz bunu öğrencilerle birlikte açığa çıkarmaya çalışıyoruz. Önce ana fikri yani verilmek istenen değeri buluyoruz. Canlandırma ve zit tepki yoluyla da olabilir."

Öğretmenlere yaptıkları incelemelere göre Türkçe ders kitaplarındaki metinlerde en çok hangi değerlerin yer aldığına ve bu değerlerin yeterliliğine dair soru yöneltilmiştir. Öğretmenlerle yapılan görüşmelere göre üzerinde en çok durulan değerler temalara göre farklılık göstermektedir. Özellikle Milli Mücadele ve Atatürk temasında vatanseverlik değeri vurgulanmıştır. Erdemler temasında ise değerlerin yoğun olduğu ifade edilmektedir. Aşağıdaki tabloda çalışmaya katılan öğretmenlerin incelemelerine göre metinlerde en çok yer alan değerler ve yeterliliklerine ilişkin bulgular yer almaktadır. 
Tablo 7: Öğretmenlerin İncelemelerine Göre Metinlerde En Çok Yer Alan Değerler ve Bu Değerlerin Yeterlilikleri

\begin{tabular}{|c|c|}
\hline Kategori & Kodlar $(f)$ \\
\hline Değerler & $\begin{array}{l}\text { Yardımseverlik (7), sevgi (6), vatanseverlik (5), sorumluluk (2), iyilik yapmak (2), sayg1 } \\
\text { (2), dürüstlük (2), dostluk (2), paylaşımcı olmak (1), dayanışma (1), empati (1), çalışkan- } \\
\text { lık (1), hoşgörü (1) }\end{array}$ \\
\hline Yeterli & Değerlerin varlığı konusunda kitabın yeterli olması (2), ana değerlerin yeterli olması (1) \\
\hline Yetersiz & $\begin{array}{l}\text { Etkinliklerin değer aktarımını desteklememesi (4), değerlerin sadece belli temalarda } \\
\text { yoğunlaşması (3), değerleri aktarmada kitabın yetersiz kalması (2), değerlere bütün } \\
\text { temalarda daha sık yer verilmesi gerektiği (2), bir metinde tek bir değere odaklanılması } \\
\text { (1), önemli bulunan değerlere yer verilmemesi (1) }\end{array}$ \\
\hline
\end{tabular}

Yapılan görüşmelerde Türkçe öğretmenleri kitapta en çok yer verilen değerlerin yardımseverlik, sevgi ve vatanseverlik olduğunu belirtmişlerdir. Metinleri inceleyen öğretmenlerle yapılan görüşmelerde, öğretmenlerin büyük çoğunluğu metinlerdeki değerlerin yeterli olmadığını düşünmektedir. Etkinliklerin değer aktarımını desteklememesi, değerlerin sadece belli temalarda yoğunlaşması ve değerleri aktarmada kitabın yetersiz kalması en çok üzerinde durulan sebeplerdir. Değerlerin yeterli olduğunu düşünen öğretmenler ise, değerlerin varl1ğ1 konusunda kitabın ve kitaptaki ana değerlerin de yeterli olduğu görüşlerini belirtmektedir. Bu düşüncelere Ö5 ve Ö9 kodlu öğretmenlerin görüşleri örnek verilebilir:

"Ben çok yeterli olduğunu düşünmüyorum. Verilmek istenen mesaj daha arka planda kalyyor. Tamam, metin güzel ama metnin etkinliklerine geçtiğimizde değerlerle ilgili bir şey olduğunu düşünmüyorum. Yüzeysel geçiliyor. Biz çocuğu yönlendirmezsek sadece kitap üzerinden gidersek çocuktan bir verim alamıyoruz." (Ö5)

"8 temayı inceledim. Değerlerin bazı temalarda daha yoğun olduğunu gördüm. Özellikle Erdemler temasında değerler çok yoğun bir şekilde vardl. Çocuklar da değerleri işlemeyi seviyorlar gözlemlediğim kadarıyla. En çok rastladiğım değerler ise sevgi değeri, dostluk değeri, Milli Mücadele ve Atatürk temasında vatanseverlik değeri oldu. Neredeyse çoğu değer vardı ama aklıma ilk gelen bunlar." (Ö9)

Çalışmaya katılan öğretmenlere göre metinlerde en çok yer verilmesi gereken değerlerin neler olduğu ve ders kitaplarının bu konudaki yeterliliği sorulmuştur. Öğretmen görüşleri aşağıda yer almaktadır. 


\begin{tabular}{|c|c|}
\hline Kategori & Kodlar $(f)$ \\
\hline Değerler & $\begin{array}{l}\text { Sayg1 (7), sevgi (5), yardımlaşma (4), adil olma (3), hoşgörü (3), dürüstlük (3), payla- } \\
\text { şımcı olmak (2), barış (2), vatanseverlik(2), alçakgönüllülük (1), iyilik (1), misafirper- } \\
\text { verlik (1), empati (1), sorumluluk (1), temizlik (1) }\end{array}$ \\
\hline Yeterli & $\begin{array}{l}\text { Değeri tanıma noktasında yeterli olması (1), yeterli sayıda yer verilmesi (1), erdemler } \\
\text { temasında değerlerin kolayca kazanılması (1) }\end{array}$ \\
\hline Yetersiz & Değerler arttırılabilir (2) \\
\hline $\begin{array}{l}\text { Kismen } \\
\text { yeterli }\end{array}$ & $\begin{array}{l}\text { Temaya göre değerlerin yoğunluğunun değişmesi (1), bazı değerlere yeterince yer } \\
\text { verilmemesi (1) }\end{array}$ \\
\hline
\end{tabular}

Yukarıdaki tabloya bakıldığında çalışmaya katılan öğretmenlerin metinlerde en çok yer verilmesini istedikleri değerin saygı değeri olduğu görülmektedir. Saygı değerinden sonra metinlerde en çok yer almasını istedikleri değerler sevgi, yardımlaşma, adil olma, hoşgörü, dürüstlük, vb. değerlerdir.

Çalışmaya katılan öğretmenlere metinlerde bulunmasını istedikleri değerlere yeteri kadar yer verilip verilmediği sorulduğunda yeterli olduğunu düşünen öğretmenler bu görüşlerini; değeri tanıma noktasında yeterli olması, yeterli sayıda yer verilmesi ve Erdemler temasında değerlerin kolayca kazanılması olarak gerekçelendirmektedir. Yetersiz olduğunu belirten öğretmenler değerlerin arttırılması gerektiğini söylemektedir. Kısmen cevabını veren öğretmenler ise temaya göre değerlerin yoğunluğunun değiştiğini ve bazı değerlere yeterince yer verilmediğini vurgulamaktadır. Bu düşüncelere Ö5 ve Ö6 kodlu öğretmenlerin görüşleri örnek verilebilir:

"Temaya göre değişiyor. Bazı temalarda çok yoğunlukla üzerinde durduğu halde diğer temaya geçince tamamen kopabiliyor değerden. O yüzden ben biraz bağlantısı olduğunu düşünüyorum. ”(Ö5)

"En çok eksik bulduğum değerler olacak tabi ki. Barlş, misafirperverlik, adil olma, başkasinin hakkina saygı duyma bunlar.”(Ö6)

Aşağıdaki tabloda çalışmaya katılan öğretmenlerin metinlerde işlenen değerler öğrencilerde farkındalık yaratıyor mu, öğrencilerin davranışlarına yansıyor mu? sorusu ile ilgili görüşleri yer almaktadır. 
Tablo 9: Metinlerde İşlenen Değerlerin Öğrencilerde Farkındalık Yaratma ve Davranışlarına Yansıması İle İlgili Öğretmen Görüşleri

\begin{tabular}{ll}
\hline Kategori & Kodlar $(f)$ \\
\hline Evet & $\begin{array}{l}\text { Sinıf içi iklime olumlu etkisi (1), öğrencilere hoşgörü kazandırması (1), öğren- } \\
\text { ve }\end{array}$ \\
cilerde empati değerini arttırması (1), sinıf disiplinini sağlaması (1), çevre duyar- \\
lilığının artması (1), derste işlenen metnin öğrencilerin davranışlarına olumlu \\
yansıması (1), değer kazanımının somut olarak gözlemlenmesi (1)
\end{tabular}

\section{Hayır}

ve
Nedenleri $\quad$ Değeri içselleştirememesi (1)

Davranışa yansıtamama (2), değer farkındalığının öğrenciye göre değişmesi (1),

Kismen kız öğrencilerin değerleri daha iyi uygulaması (1), bazı değerlerin somut olarak

ve gözlenememesi (1), değeri kazandırmada okul kültürünün önemi (1), pekiştirece

nedenleri göre değişiklik göstermesi (1), metinlerin farkındalık yaratmada etkili olması (1), somutlaştırıldığında kalıcı olması (1)

Metinlerde işlenen değerlerin öğrencilerde farkındalık yaratma durumu ile ilgili olumlu görüş belirten öğretmenler derste işlenen metnin öğrencilerin davranışlarına olumlu yansıması ve sınıf içi iklime olumlu etkisi yorumlarıyla bu görüşü desteklemektedirler. Hayır cevabını veren bir öğretmen bu duruma gerekçe olarak öğrencilerin değeri içselleştirememesini göstermektedir. Bu soruyu kısmen olarak cevaplayan öğretmenler öğrencilerin davranışa yansıtamaması, kız öğrencilerin değerleri daha iyi uygulaması ve değer farkındalığının öğrenciye göre değişmesi gibi söylemlerle bu düşüncelerini gerekçelendirmektedirler. Ö $\breve{g}$ retmen görüşlerine örnek şöyledir:

"Metinlerdeki değerlerin öğrencilerde davranış değişikliği yaratması yavaş izlenebilen bir süreç. Bunu özellikle hoşgörü ve benzer değerler için daha belirgin bir şekilde gözlemledim. Özellikle metin sonrası ve öncesi yaptırdı̆̆ım etkinlikler ve verilen sorumluluklarla daha da etkili olduğunu öğrencilerimde farkındalık yarattı̆̆ını söyleyebilirim." (Ö7).

Öğretmenlere değerleri doğru aktarabilmek için hangi tür metinleri tercih ettikleri sorulmuştur. Öğretmen görüşleri aşağıda yer almaktadır.

Tablo 10: Değerleri Doğru Aktarabilmek İçin Öğretmenlerin Kullanmayı Tercih Ettiği Türler

\begin{tabular}{ll}
\hline Kategori & Kodlar $(f)$ \\
\hline $\begin{array}{l}\text { Bilgilendirici } \\
\text { türler }\end{array}$ & Öğretici metinler (1), deneme, serüven yazıları, gezi yazısı (1) \\
\hline $\begin{array}{l}\text { Hikaye edici } \\
\text { türler }\end{array}$ & $\begin{array}{l}\text { Olaya dayalı metinler (9), tiyatro (2), masal (2), hikâye, masal, fabl(1), } \\
\text { karikatür (1) }\end{array}$ \\
\hline Şiir & Şiir (4) \\
\hline
\end{tabular}


Yukarıdaki tablo incelendiğinde çalışmaya katılan öğretmenlerin büyük çoğunluğunun değerleri doğru aktarabilmek için tür olarak olaya dayalı metinleri tercih ettiği görülmektedir. Olaya dayalı metinlerden sonra en çok tercih edilen metin türü şiir olmuştur. Bu düşüncelere Ö2 kodlu öğretmenin görüşü örnek verilebilir.

“... olay metinlerini daha çok kullanırsak çocuklar üzerinde en azından olayı içinde yaşayabilme duygusunu hissediyor çocuk ve kendini özdeşleştirebiliyor olay metinleriyle. Bilgilendirici metni okurken de slknlyyor ve bilgilendirici metin dolaylsiyla vermek istediğimiz değeri tam olarak veremiyor. Bundan dolayl eğer kitabın yazarı ben olmuş olsaydım olay ağırlıklı metinleri daha çok kullanırdım." (Ö2)

Aşağıdaki tabloda çalışmaya katılan öğretmenlerin değerlerle ilgili görüş ve önerileri yer almaktadır.

Tablo 11: Değerlerle İlgili Öğretmenlerin Görüş ve Önerileri

\begin{tabular}{|c|c|}
\hline Kategori & Alt kategori $(f)$ \\
\hline $\begin{array}{l}\text { Ĕgitim- } \\
\text { Öğretim } \\
\text { Boyutu }\end{array}$ & $\begin{array}{l}\text { Ayın değeri uygulaması (4), pano çalışmalarının yapılması (3), okulun vizyonu ha- } \\
\text { line gelmesi (2), değerlerle ilgili projeler yapılması (2), farklı derslerde de değerlere } \\
\text { yer verilmesi gerektiği (2), değerlerin metinler aracıllı̆ıyla aktarılması (2), eğitimde } \\
\text { değerlerin önemli bir yerinin olması (2), değerlerin ders kitabıyla sınırlı kalmaması } \\
\text { (2) değer aktarımının bilinçli yapılması gerektiği (1), değerleri yaparak yaşayarak } \\
\text { öğrenme (1) değerlerle ilgili okul dışı etkinliklerin yapılması (1), tiyatrolar, oyunlar, } \\
\text { yarışmalar yoluyla değer aktarımı (1), değerlere gereken önemin verilmemesi (1), } \\
\text { ayın örnek öğrencisi uygulaması (1), örnek davranışların ödüllendirilmesi (1), değer- } \\
\text { ler günü uygulaması (1), okul içi etkinliklerin yapılması (1) }\end{array}$ \\
\hline $\begin{array}{l}\text { Öğretmen } \\
\text { Boyutu }\end{array}$ & $\begin{array}{l}\text { Öğretmenlerin değer aktarımında aktif rol alması (2), öğretmenlerin değerlerin far- } \\
\text { kında olmaması (2), öğretmen ve ailenin iş birliği içerisinde olması (2), öğretmenin } \\
\text { rol model olması (2), öğretmenlerin iş birliği içerisinde olması (2), lisans eğitiminin } \\
\text { değerler eğitimi konusunda yetersiz kalması (1), öğretmenin yaratıcılığının önemi } \\
\text { (1), öğretmenin eğitim becerisinin önemi (1), öğretmenin yetisinin önemi (1), öğret- } \\
\text { menin değer aktarımında sorumluluk alması (1), öğretmenin kendini eğitmesi (1) }\end{array}$ \\
\hline $\begin{array}{l}\text { Aile ve Çevre } \\
\text { Boyutu }\end{array}$ & $\begin{array}{l}\text { Velinin sorumluluk üstlenmemesi (2), ailelere değerlerle ilgili seminer verilmesi (2), } \\
\text { değerleri oluşturmada arkadaş çevresinin etkisi (1) }\end{array}$ \\
\hline $\begin{array}{l}\text { Toplum } \\
\text { Boyutu }\end{array}$ & $\begin{array}{l}\text { Toplumun değerler konusunda eğitilmesi (1), ülkenin vizyonu haline gelmesi (1), } \\
\text { bilinçsizce televizyon izlemenin değerlere olumsuz etkisi (1), televizyondaki kişilerin } \\
\text { rol model alınması (1), toplumun yapı taşı olması (1) }\end{array}$ \\
\hline
\end{tabular}

Çalışmaya katılan öğretmenlerin değerlerle ilgili görüş ve önerileri incelendiğinde; eğitim-öğretim boyutu, öğretmen boyutu, aile ve çevre boyutu ve toplumsal boyut olarak 4 başlıkta toplandığı görülmektedir. Eğitim-öğretim ile ilgili olarak ayın değeri uygulamasının yapılması, pano çalışmalarının yapılması, değerlerin metinler aracılığıyla aktarılması gibi görüş ve öneriler ön plâna çıkmaktadır. Öğretmenlerin ayrıca ailelere değerlerle ilgili seminer verilmesi ve toplumun değerler konusunda eğitilmesi de diğer boyutlarda öne çıkan düşüncelerdir. 
Değerlerle ilgili öğretmenlerin görüş ve önerilerini yansıtan örnek şöyledir:

Ö9: "Değerler toplumun yapı taşıdır. Biz ögretmenler bize düşen bu sorumluluğun farkında olmalıyız. Kazanımda olsun ya da olmasın Milli Eğitim'in ilk üç maddesindeki temel amacımız iyi insan yetiştirmek. Bunun bilincinde olmalyyı. Taşın altına elimizi koymaktan çekinmemeliyiz."

\section{Sonuç ve Tartışma}

2018-2019 eğitim-öğretim yılında Bitlis ilinde okutulan 6. sınıf Eksen Yayınları Türkçe ders kitabındaki metinler değerler eğitimi açısından incelendiğinde metinlerde en çok yer alan değerin sorumluluk değeri olduğu görülmüştür. Daha sonra vatanseverlik, sevgi ve saygı değerleri gelmektedir. Estetik duyguların geliştirilmesi ve alçakgönüllülük değerlerine metinlerde rastlanmamıştır. Doğan ve Gülüşen (2011) 6, 7 ve 8. sınıf Türkçe ders kitaplarını inceledikleri çalışmada 76 metinde en fazla ulusal değerlere ve sorumluluk değerine yer verildiğini belirtmişlerdir. Bu sonuç sorumluluk değeri açısından çalışmamızla örtüşmektedir. Yaman, Taflan ve Çolak (2009) çalışmalarında ilköğretim ikinci kademe Türkçe ders kitaplarındaki metinlerde en çok sosyal değerlere yer verildiğini belirtmişlerdir. Bu çalışmada da sevgi ve saygı değerlerine daha çok rastlanması iki çalışmanın birbirini desteklediğini göstermektedir.

Temalara göre değerler incelendiği zaman değerlerin en çok yer aldığı temanın 64 defa değerle karşılaşılan Erdemler teması, değerlerin en az yer aldığ 1 temanın ise 14 defa değerle karşılaşılan Bilim ve Teknoloji teması olduğu görülmektedir. Gül (2017) 5. sınıf Türkçe ders kitabını değerler eğitimi açısından incelediği çalışmasında değerlerin temalara dağılımında homojen bir yapının görülmediği sonucuna ulaşmıştır. Bizim çalışmamızda da benzer şekilde değerlerin temalara homojen bir şekilde dağılmadığı görülmektedir.

Metin türlerine göre değerler incelediğinde hikâye edici metin türünde değerlere daha fazla yer verildiği görülmektedir. Hikâye edici metinlerde en çok rastlanan değerler yardımlaşma-dayanışma ve sorumluluk değerleridir. Fırat ve Mocan (2014) Türkçe ders kitaplarındaki hikâyelerde yer alan değerleri inceledikleri çalışmada metinlerde ağırlıklı olarak ahlakî-manevi değerlere yer verildiği sonucuna ulaşmışlardır. Bu noktada iki çalışmanın benzer sonuçlarının olduğu söylenebilir.

Bulgulara göre değerlere en az yer verilen metin türü şiirdir. Şiirlerde en s1k rastlanan değerin vatanseverlik olduğu görülmektedir. Tokcan (2017) çalışma- 
sında Fazıl Hüsnü Dağlarca'nın çocuk şiirlerini değerler eğitimi açısından incelemiş ve incelenen şiirlerde en çok sevgi değerine rastlamıştır. Bu çalışmada incelenen şiirlerde ise en çok vatanseverlik değerine rastlanılmıştır.

Bilgilendirici metin türünde en s1k rastlanan değerin sorumluluk değeri olduğu görülmektedir. Özgüven, iyimserlik, estetik duyguların geliştirilmesi, misafirperverlik, şefkat-merhamet, selamlaşma, alçakgönüllülük değerlerine ise bilgilendirici metinlerde rastlanmamaktadır.

Öğretmen görüşleri incelendiğinde Türkçe öğretmenlerinin değerlerle ilgili düşünceleri ve Türkçe ders kitabındaki metinleri değerler açısından incelemelerine göre değerlerin iyi insan yetiştirme amacına sahip olduğu ve değerlerin evrensel olduğu sonucuna ulaşılmıştır. Ayrıca öğrencilerin öğretmenlerin hareketlerini taklit ettiği belirtilerek öğretmenlerin değerleri aktarırken olumlu rol model olması gerektiği de ulaşılan sonuçlar arasındadır. Çağlayan (2018) çalışmasında değerler eğitiminde öğretmen davranışlarının öğrenciler üzerinde etkisinin fazla olduğu sonucuna ulaşmıştır. Bu noktada iki araştırma sonucunun birbirini desteklediği görülmektedir.

Değerlerin ders kitaplarındaki metinler aracıllğıyla verilmesi gerektiği öğretmenlerin üzerinde durduğu bir konu olarak dikkat çekmektedir. Değerler eğitimine gerekli önemin verilmediği ve sistemden kaynaklanan sorunlar nedeniyle değerlerin geri plânda kaldığı görüşleri de çalışmanın sonuçları olarak karşımıza çıkmaktadır. Fidan (2009)'ın çalışmasında da değer öğretimi için en önemli şeyin değerleri yaşamak olduğu, bireylerin değere verdikleri anlamların farklı olduğu, değer öğretiminin bilgi kadar önemli olduğu, medyanın değer öğretiminde okulun ve öğrenmenin etkisini azalttığı sonuçlarına ulaşılmıştır.

Türkçe öğretmenlerinin çoğu değerlerin ders plânlarında kazanım olarak yer alması gerektiğini söylemiş, bu durumu öğretmen açısından farkındalığı arttıracağı ve öğretmenlerin değerlerle ilgili derslere hazırlıklı geleceği görüşlerine dayandırmışlardır. Değerler eğitimi, öğrencinin genel başarısını etkileyecek şekilde programda kazanım olarak yer almalıdır. Böylece değerler eğitimi konusunda öğretmenlerin farkındalıkları ve sorumlulukları artacak ve öğretmenler değerler eğitimine yeterli zamanı ayırabileceklerdir.

Çalışma sonucunda Türkçe derslerinde değerleri aktarmak için en çok kullanılan yöntem ve tekniklerin; canlandırma, soru-cevap ve tartışma olduğu tespit edilmiştir. Konu ve metin aracıllğıyla ön plâna çıkarma ve güncel olaylarla örneklendirme de öğretmenlerin kullandığı yollar olarak görülmektedir. Balcı 
ve Yelken (2013) ise çalışmalarında öğretmenlerin değer öğretiminde en etkili buldukları yöntemin örnek olay incelemesi olduğu sonucuna ulaşmıştır. $\mathrm{Bu}$ noktada iki çalışma farklılaşmaktadır. Atalay (2013) ise değerler eğitimi açısından Türkçe ders kitaplarını incelediği çalışmasında drama, rol yapma, empati etkinlikleri, tartı̧̧ma, örnek olay, eğitsel oyun, gezi-gözlem türünden yöntem ve tekniklere daha çok ağırlık verilmesi gerektiği sonucuna ulaşmıştır. Bu çalışmada bazı yönlerden bizim çalışmamızla örtüşen sonuçlar ortaya konmuştur.

Türkçe ders kitabındaki 40 metni inceleyen öğretmenler; bu metinlerde en çok yardımseverlik, sevgi ve vatanseverlik değerlerine rastladıklarını söylemektedirler. Türkçe ders kitabındaki metinler incelendiğinde ise en çok sorumluluk değerine rastlandığı, bunu vatanseverlik, sevgi ve saygı değerlerinin takip ettiği görülmektedir. Metinlerdeki değerlerin yeterli olmadığını belirten öğretmenler; etkinliklerin değer aktarımını desteklemediğini, değerlerin sadece belli temalarda yoğunlaştığını ve değerleri aktarmada kitabın yetersiz kaldığını da belirtmektedir. Kitaptaki metinlerin analizi sonucunda da değerlerin Erdemler temasında yoğunlaşmış olması öğretmenlerin bu görüşünü desteklemektedir.

Bu çalışmanın sonucunda saygı, sevgi ve yardımlaşma değerleri Türkçe öğretmenlerinin metinlerde en çok yer almasını istedikleri değerler olarak görülmektedir. Balcı ve Yelken (2013)'in çalışmasında İlköğretim Sosyal Bilgiler programında yer alan değerler ve değer eğitimi uygulamalarıly ilgili öğretmenler adil olma, barış, dürüstlük, duygu ve düşüncelere sayg1 değerlerinin önem derecesi açısından ilk sıralarda yer aldığını tespit etmişlerdir. Bizim çalışmamızda da öğretmenlerin en çok önem verdiği değerlerden birinin saygı değeri olduğu görülmektedir.

Metinlerde işlenen değerlerin öğrencilerin davranışlarında farkındalık yarattığ 1 ve sınıf içi iklimde önemli rolünün olduğu sonucuna da ulaşılmıştır. Ateş (2014) ilkokul ve ortaokul öğretmenlerinin değerler eğitimi ve uygulamalarına yönelik görüşleri üzerine yaptığı çalışmada değerler eğitimi konularının okulda, sosyal faaliyetler ya da etkinlikler olarak plânlanması gerektiği sonucuna ulaşmıştır. Bu yönüyle bizim çalışmamızla birbirini desteklemektedir. Değerleri doğru aktarabilmek için öğretmenlerin çoğu olaya dayalı metinleri tercih etmektedir. Türkçe ders kitabındaki metinler incelendiğinde de değerlerin en çok öyküleyici metinlerde yer almış olması öğretmen görüşleriyle tutarlılık göstermektedir.

Araştırmada ulaşılan sonuçlar genel olarak değerlendirildiğinde değerlerin Türkçe ders kitabındaki metinlerde dengeli bir dağılım göstermediği, ağırlıklı 
olarak bazı temalarda ve öyküleyici metin türünde yoğunlaştığı görülmektedir. Ders kitaplarındaki metinlerde önemli bir yere sahip olan değerler öğretmenler tarafından da önemli görülmektedir. Buna ek olarak değerler eğitimi için öğretmenler sorumluluklarının bilincindedirler. Ayrıca değerler eğitiminin tek başına ders kitaplarındaki metinlerle verilemeyeceği, okul, öğretmen ve veli gibi eğitim paydaşlarının işbirliği neticesinde başarıya ulaşacağı ortaya çıkmıştır.

Bu çalışmanın sonuçlarından hareketle Türkçe ders kitaplarına seçilen metinlerin ilettiği değerler açısından zengin olmasına, temalara ve metin türlerine dengeli bir dağılım göstermesine ve değerlerin tamamının önemli olduğu düşüncesiyle hareket edilmesine azami gayret gösterilmesi gerektiği söylenebilir. Değerler eğitimi konusunda öğretmenlerin farkındalıkları arttırılmalı, lisans eğitimlerinde bu konuya ayrıca yer verilmelidir. Değerler eğitiminin Türkçe öğretim programında da bir öğrenme alanı olarak yer alması gerektiği düşünülmektedir. Ayrıca değerler eğitiminde eğitim paydaşlarının işbirliğini destekleyecek uygulamalara ağırlık verilmelidir.

\section{Kaynakça}

Atalay, D. (2013). 2012-2013 öğretim yllı ilköğretim 6.sinlf Türkçe ders kitaplarında yer alan 'Sevgi ve Duygular' temalarının değerler eğitimi açısından incelenmesi(Yüksek lisans tezi)Celal Bayar Üniversitesi Sosyal Bilimler Enstitüsü, Manisa.

Ataman, A. (2001). Konu alanı ders kitabı inceleme kılavuzu Türkçe 1-8. Nobel.

Ateş, F. (2014). Illkokul ve ortaokul öğretmenlerinin değerler eğitimi ve uygulamalarına yönelik görüşleri üzerine nitel çalı̧̧ma (Yüksek lisans tezi)Yeditepe Üniversitesi Sosyal Bilimler Enstitüsü, İstanbul.

Balcı, A. F. ve Yanpar Yelken, T. (2013). İlköğretim sosyal bilgiler programında yer alan değerler ve değer eğitimi uygulamaları konusunda öğretmen görüşleri. Ahi Evran Üniversitesi Kırşehir Eğitim Fakültesi Dergisi(KEFAD), 14(1), 195-213

Coşkun, V. ve Sargın, M. (2007).Yapılandırmacı yaklaşım çerçevesinde İlköğretim 6. sınıf Türkçe ders kitabında strateji, 16. Ulusal Ĕgitim Bilimleri Bildiriler (Editör: Yrd. Doç. Dr. Ergin ERGİNER), 1, s. 334-337, Gaziosmanpaşa Üniversitesi, 5-7 Eylül, Tokat.

Çağlayan, E. (2018). Değerler ĕgitimi ve uygulamalarına yönelik veli ve öğretmen tutumlarının değerlendirilmesi: Bingöl örneği (Yüksek lisans tezi).Bingöl Üniversitesi Sosyal Bilimler Enstitüsü, Bingöl. 
Çakıroğlu, A. (2013). Değerler etkisinde korku kültürünün etkisi. (Yüksek lisans tezi). Bolu Abant İzzet Baysal Üniversitesi, Eğitim Bilimleri Enstitüsü, Bolu.

Çeçen, M. ve Çiftçi, Ö. (2007). İlköğretim 6. sınıf Türkçe ders kitaplarında yer alan metinlerin tür ve tema açısından incelenmesi. Millî Eğitim, 173, 39- 49.

Çelikpazu, E. ve Aktaş, E. (2011). MEB 6, 7 ve 8. sınıf Türkçe ders kitaplarında yer alan metinlerin değer iletimi açısından incelenmesi. Turkish Studies, 6(2), 413-424.

Doğan, B. ve Gülüşen, A. (2011). Türkçe ders kitaplarındaki (6-8) metinlerin değerler bakımından incelenmesi. Sosyal Bilimler Dergisi, 1, 75-99.

Fırat, H. ve Mocan, A. (2014). Türkçe ders kitaplarındaki hikâyelerde yer alan değerler. Türkiye Sosyal Araştırmalar Dergisi,3, 25-49.

Fidan, N. (2009). Okulda öğrenme ve öğretme.(3. Baskı). Pegem.

Gül, M. (2017). Türkçe ders kitabındaki metinlerin (5. sınıf) değerler eğitimi yaklaşımıyla incelenmesi. Erciyes Journal of Education,1(1), 59-78.

1739 sayılı Milli Eğitim Temel Kanunu(1973). Resmî Gazete (Say1: 14574).

Kaygana, M., Yapıcı, Ş. ve Aytan, T. (2013). Türkçe ders kitaplarında değer eğitimi. International Journal of Social Science, 7, 657-669.

Kızıler, H. Ve Canikli, İ. (2016). Değerler eğitimi. Karabük: Denem Yayınları.

Miles, M. B. Ve Huberman, A. M. (1994). Qualitative data analysis: An expanded sourcebook. Sage.

Özbay, M., ve Karakuş Tayşi, E. (2011). Dede Korkut Hikâyeleri’nin Türkçe öğretimi ve değer aktarımı açısından önemi. Pegem Ĕ̆itim ve Öğretim Dergisi, 1(1), 21-31.

Tokcan, F. (2017). Fazıl Hüsnü Dağlarca'nın çocuk şiirlerinin değerler ĕgitimi açısından incelenmesi(Yüksek lisans tezi).Necmettin Erbakan Üniversitesi, Eğitim Bilimleri Enstitüsü, Konya.

Yaman, E. (2016). Değerler eğitimi eğitimde yeni ufuklar. Akçağ.

Yaman, H.,Taflan, S. ve Çolak, S. (2009). İlköğretim ikinci kademe Türkçe ders kitaplarında yer alan değerler. Değgerler Ĕ̈itimi Dergisi,7, 107-120.

Yapıc1, M. (2004). İlköğretim I. kademe ders kitaplarının öğrenci düzeyine uygunluğu. Uluslararası Insan Bilimleri Dergisi, 1(1), 121-130. 
Extended Abstract

\section{The Examination of Texts in Turkish Coursebooks in Terms of Values Education and Their Evaluation According to Teachers' Opinions}

Hatice COŞKUN, Corresponding Author, Assistant Professor.

Van Yüzüncü Yıl University, Van /Turkey.

haticecoskun@yyu.edu.tr

https://orcid.org/0000 000204538700

Gizem Ezgi DERSE, Master Degree Student.

Van Yüzüncü Yıl University, Van /Turkey.

gizemezgi@gmail.com

https://orcid.org/0000 000192414849

Article Type: Research Article

https://doi.org/10.34234/ded.738543

Received Date: 17.05 .2020

Accepted Date: 12.03 .2021

Published Date: 25.06.2021

\section{Introduction}

The new thoughts and discussions that have come into prominence in recent years show that the main purpose of education is much more than developing a student's cognitive skills. Education aims to ensure that the individuals develop an identity that is open for improvement in terms of thought and character, who do not deviate from the values that compose them and passing these values on to future generations. This goal is an important building block in bringing the society to the intended level of modern civilization. In order for the society to 
reach the intended level of modern civilizations, individuals who constitute the society must embrace certain behaviors as value.

Values are the elements that establish how people behave, guide to good and decent life and help individuals and society thrive. From this perspective, values and values education is of great importance in education and training (Çakıroğ$\mathrm{lu}, 2013$, p. 6). It is observed that the values education in education and training aims to enrich society with individuals who can make sound judgments, exhibit sound behaviors and feel positive emotions. Therefore, values education should be offered in a well-structured manner at all levels from the lowest stage to the highest stage in education.

Values are thought to the students within a plan through curricula created for formal education institutions. And Turkish language curriculum serves this purpose as well. Turkish lesson aims to teach effective listening, speaking accurately in line with the standards, using grammar rules and reading and writing well as well as ensuring that the student acquires national, moral, social and universal values (Doğan ve Gülüşen, 2011, p. 77). Turkish lesson should also ensure that individuals acquire universal and social values, while enabling them to communicate properly with others and develop language skills. An individual who learn his/her own culture and mother tongue in Turkish lesson will develop, through such learning, an increased awareness about the values of the society he/she lives in. For this reason, it is very important to teach the values education in Turkish lessons. Texts are the primary means for the transfer of values in Turkish lessons. The Turkish lessons make sure that students comprehend the values through texts so that they can acquire the appropriate behaviour. Considering the studies conducted in the field, it was observed that there is a need for a study that examines the texts in the textbooks in terms of values education and that evaluates them according to teachers' opinions.

Therefore, this study aims to examine the texts available in the 6th grade Turkish textbook of Eksen Yayınları (Eksen Publishing) for 2018-2019 in terms of the values education and evaluate them according to teachers' opinions. The sub-objectives that are discussed as part of such aim are as follows:

-To determine the values covered in the texts available in the 6th grade Turkish textbook of Eksen Yayınları, the values are categorized into themes and the frequency of their appearance in text are examined;

-To determine the teachers' perceptions of the values conveyed in the text, values are evaluated according to teachers' opinions. 


\section{Method}

The study was utilized qualitative research method, the data were collected using qualitative data collection techniques and analysed by qualitative analysis.

\section{Study Group and Study Document}

40 texts available in the 6th grade Turkish textbook of Eksen Yaylnlarl for 20182019 were used as the study document. The study group consisted of 10 Turkish teachers who work at secondary schools in Bitlis province.

\section{Development of Data Gollection Tools, Data Gollection and Data Analysis}

Document review: In the first stage, 27 values covered in the MEB (Ministry of National Education) Values Education Directive (2018) were listed in order to review the values in the texts available in the 6th grade Turkish textbook of Eksen Yayınlarl for 2018-2019. Based on this list, each text in the Turkish textbook was analysed in terms of the values it conveys. Sentence units were taken into account in the analysis process. The values were identified after the analysis of texts and the frequency of these values, themes and text types was investigated. Coder reliability was made for the reliability of document review. According to the reliability formula of Miles and Huberman (1994), 80\% coding consistency was achieved and the analysis was completed.

Semi-structured interview form: A semi-structured interview form was used to get perceptions of value of teachers and their opinions on the texts available in Turkish textbooks. 11 questions were included in the form as a result of expert opinions and pilot application. In the data collection process, 10 volunteering Turkish teachers were asked to read and review 40 texts available in the Turkish textbook used in the study. Afterwards, interviews were made with the teachers. Content analysis used for the analysis of data. For the reliability of analysis, inter-coder reliability was considered.

\section{Findings}

The most frequent value in the texts of Turkish textbook is the responsibility value. Following this, comes the values of patriotism, love and respect. Development of aesthetic feelings and humility values were not found in these texts. 
The theme with the most values was the Virtues and the theme with the least values was the Science and Technology. When the values are analysed by the type of texts, it is found that values are more frequent in the narrative text type. The type of text that includes the lowest number of occurrences of values is poetry. It is observed that the most common value covered in the informative text type is the responsibility. The most common values found in the narrative text type are responsibility and solidarity values. It is observed that the most common value covered in poems is patriotism.

It is found that tolerance, love and benevolence are the values that most occurred to the mind of participating teachers in relation to the concept of values education. When the opinions of teachers about how values are introduced are examined, the emerging ideas are that the values should be introduced as part of education and that they should be a role model when conveying the values.

It is observed that teachers use associations and practice certain methods and techniques to convey values to students in Turkish lessons. In the association method, featuring the values through subject and text and exemplifying with current events are the prominent techniques. The methods and techniques they use the most are animation, question and answer and discussion.

\section{Discussion}

When the texts available in the 6th grade Turkish textbook of Eksen Yayınları for 2018-2019 are analysed in terms of values education, it was found that the most frequent value was the responsibility. Following this, comes the values of patriotism, love and respect. Development of aesthetic feelings and humility values were not found in these texts. These findings are similar to those found in the studies conducted by Doğan and Gülüşen (2011) and Yaman, Taflan and Çolak (2009).

When the values are analysed thematically, the theme which contained the most values was the Virtues and the theme with the lowest number of values was the Science and Technology. In the study where he studied 5th grade Turkish textbook in terms of values education, Gül (2017) concluded that no homogeneous structure was observed in the distribution of values by themes.

When the values are analysed according to the type of texts, it is observed that values are covered more in the narrative text type. The most common values found in the narrative texts are solidarity and responsibility. In a study where 
the values covered in the stories available in Turkish textbooks are examined, Firat and Mocan (2014) concluded that moral and spiritual values were predominately covered in the texts. At this point, it can be suggested that the two studies have similar findings.

Based on the analysis of interview data, it could be said that the students imitate the acts of teachers and thus, teachers should be a positive role model when conveying the values. In his study, Çağlayan (2018) concluded that behaviors of teacher have an important influence on students in values education. In this regard, the findings of the two studies support each other.

The results of the study show that the most commonly used methods and techniques by teachers to convey the values are animation, question and answer and discussion. Featuring the values through subject and text and exemplifying with current events were also found to be the prominent techniques used by teachers. On the other hand, Balc1 and Yelken (2013) concluded that the most effective method that teachers consider in values education is the case study. At this point, the two studies differ from each other. In the study where he examined the Turkish textbooks in terms of values education, Atalay (2013) concluded that methods and techniques in the form of drama, role-playing, empathy activities, discussion, case study, educational game/trip and observation should be more incorporated in textbooks. The findings of the aforementioned study are similar, in some respect, to the ones presented in our study.

Etik Beyan / Ethical Statement: Bu çalışmanın hazırlanma sürecinde bilimsel ve etik ilkelere uyulduğu ve yararlanılan tüm çalışmaların kaynakçada belirtildiği beyan olunur. / It is declared that scientific and ethical principles have been followed while carrying out and writing this study and that all the sources used have been properly cited.

Finansman / Funding: Yazarlar, bu araştırmayı desteklemek için herhangi bir dış fon almadıklarını kabul ederler. / The authors acknowledge that they recevied no external funding in support of this research.

Yazar (lar) / Author (s): Hatice COŞKUN, Gizem Ezgi DERSE

Yazar Katkıları / Author Contributions: Hatice COŞKUN(\%50), Gizem Ezgi DERSE (\%50)

Çıkar Çatışması / Competing Interests: Yazarlar, çıkar çatışması olmadığını beyan ederler. / The authors declare that they have no competing interests. 